\title{
Conceptualizing Conviviality in Urban Landscapes
}

\author{
By Maria Beltran Rodriguez* \\ Madlen Simon ${ }^{\dagger}$
}

The research described in this paper is part of an ongoing investigation on the relationship between design solutions and the level of conviviality among users of urban landscapes, particularly within the context of areas characterized by a diverse population. This specific paper summarizes a literature review conducted on conviviality and explains the findings gathered when theoretical concepts were tested in a real environment, Superkilen park, as part of a pilot study conducted in 2015. Three broad branches are identified in the literature as necessary conditions for convivial environments: physical spaces that are flexible, changing and adaptable; processes and outcomes based in equity, integrity and democracy; and urban uses and solutions that correspond to people's needs and desires. These three conditions have been translated into three equivalent design qualities of urban landscapes that can be objectively observed: flexible, inclusive and useful. The design elements and parts of Superkilen that shared any of these attributes were documented and mapped. These first findings indicate that certain design attributes can have an effect on the conviviality performance of an urban landscape. A better understanding of the relationship between design and user's conviviality can inform architects, landscape architects, urban designers and planners on how to improve the public realm at the scale of the street, the neighborhood and the city. Keywords: Conviviality, Urban landscape design, User performance

\section{Introduction}

The main interest of this study is to find out design attributes that will foster conviviality in urban landscapes. By urban landscapes, we refer to a particular type of park within the network of public open spaces in the city. Urban parks are often highlighted for their ecological functions, as well as their experiential and cultural effects ${ }^{1}$. Lately though, the ecological function seems to be secondary, as many new internationally awarded urban landscapes show. Clemens Steenbergen ${ }^{2}$ talks about the development of the city park as a

\footnotetext{
* Graduate Student, University of Maryland, USA.

${ }^{\dagger}$ Associate Professor, University of Maryland, USA.

1 Julia Czerniak and George Hargreaves, Large parks. (Cambridge, Mass.: Princeton Architectural Press; in association with the Harvard University Graduate School of Design, 2007).

${ }^{2}$ Clemens Steenbergen, "The Formal Strategy and Grammar of Landscape Architecture" in ARRIOLA, A. Modern park design: recent trends, 38 (1993).
} 
landscape architectural model. One of the turning points he mentions is the appearance of what he calls 'The people's park': "until then the landscape architectural form could be reduced to its origins in nature. The people's park $[\ldots]$ became a recreational machine. Instead of nature, the program became the source of unity." 3 This research studies this park typology, the people's park, highly designed and programmed and not necessarily green in the traditional sense. The term 'urban landscape' - instead of park- will be used to refer to this kind of places.

In this new family of urban landscapes that put a larger emphasis on design and program than on ecology, social well being seems to play an important role and is seen as a pertinent aspect to study. Thus, finding out what aspects of design make people feel welcomed and integrated become essential aspects of this research. As well as finding out what solutions can simultaneously achieve perceiving an urban landscape individually and collectively, as partly 'ours' (i.e. an extension of our living room) and partly 'others' (i.e. respecting that space as also belonging to a larger group of people). How can we make people feel like at home and at the same time promote a tolerant and respectful attitude towards strangers? This becomes an even more important question in demographically, culturally, economically and/or ethnically diverse contexts, like the ones this research focuses on.

Thus the use of the term convivial is not arbitrary. It is picked precisely because it is not commonly used in urban studies and therefore doesn't have some of the 'baggage' and connotations associated with other terms more widely used. Most scholars promoting lively, sociable, neighborly, and friendly streets emphasize the expression "sense of community". Community generally connotes a group of people who are alike in one or more important ways - for example, the African-American community, a community of artists, the faith community, etc. In our opinion, "sense of community" no longer serves us well to characterize successful and vital places, as cities and neighborhoods are becoming more diverse. Therefore, we have adopted a word that is used in everyday language to describe social relationships and a certain kind of behavior among people. Conviviality can serve us well to study how people interact in public spaces, without the connotations of homogeneity associated with the term community.

The research project's goals are on one hand to incorporate the term convivial to the pool of knowledge of urban design studies, as a quality of the public realm that helps explain healthy social life in urban places; and on the other, to promote convivial environments.

In achieving the first goal, we reexamined the theoretical and conceptual background revolving around the study of public life and social behavior in the built environment. The literature review undertaken led to a more technical definition of the term 'conviviality', applied to urban spaces. This informed the conceptualization and operationalization of the term 'convivial', composed of three main conditions: flexibility, equity and adaptability. The use of these three dimensions bridges the gap between studies in landscape architecture and

\footnotetext{
${ }^{3}$ Steenbergen, "The Formal Strategy and Grammar of Landscape Architecture," 122.
} 
urban design and those in social justice, community planning and behavioral science. This body of literature grounds our questions about how design aspects of urban landscapes may impact the relationship of its users, their level of conviviality. For practicality matters, the three conditions from the literature have been translated into three equivalent design qualities of urban landscapes that can be objectively observed: flexible, inclusive and useful.

The second research goal is to inform on best practices that could take place in real life in order to "grow" convivial places. In achieving it, we are contrasting the literature findings by conducting a pilot study in a 'people's park', Superkilen (Copenhagen). The design elements observed and understood as being flexible, inclusive and useful, were documented and mapped. In a previous paper ${ }^{4}$ the authors defined conviviality. The present paper describes in detail the conceptualization process of the term conviviality for the study of social life in urban space. The point of this research is to create a foundation for practical application.

Once we find out what aspects of design can have an effect on conviviality, then, through the review and editing of the ordinary park maintenance plan, those findings will be included in a post-occupancy evaluation proposal, that we refer to as a "follow-up action plan for urban landscapes." This tool, instead of focusing only in the maintenance of aspects such as green and paint, will also evaluate the suitability of design features in social interaction and integration performance; in other words, it will evaluate conviviality performance of a people's park. This could ultimately allow the city to follow up the conviviality performance of an urban landscape, to evaluate implementation of design changes, and inform the way maintenance is currently done in parks.

This research aligns with international data from organizations such as the Young Foundation in the $\mathrm{UK}^{5}$ and the Grattan Institute in Australia ${ }^{6}$, on the importance of social interaction for every individual's wellbeing. One of the things that make cities livable is social interaction in the public realm, and this seems to be lacking in more and more places. It is a worldwide concern, affecting cities all over the globe, which makes it relevant and of great interest both at the research and academic level and also at the professional and political one.

\footnotetext{
${ }^{4}$ Maria Beltran and Madlen Simon, "Towards a Definition of Convivial Urban Spaces" (paper presented at the $52^{\text {nd }}$ International Making Cities Livable Conference, Bristol, UK, June 30July 2, 2015).

${ }^{5}$ Woodcraft, Bacon, Caistor-Arendar and Hackett; Foreword by Peter Hall, Design for Social Sustainability, a Framework for Creating Thriving New Communities (UK: Young Foundation, 2011)

${ }^{6}$ Kelly, Social Cities (Australia: Grattan Institute, 2012)
} 


\section{Incorporate the Term Conviviality into the Lexicon}

Conviviality is a term that is used widely in sociology ${ }^{7}$, but not as much in urban planning and design. Various scholars of urban space have identified a lack of interaction ${ }^{8}$, absence of life in the streets ${ }^{9}$, loss of social capital ${ }^{10}$, and diminishing equity ${ }^{11}$ in public spaces. We view this as a need for conviviality. ${ }^{12}$

Through a literature review, we have defined, conceptualized and operationalized the term conviviality rigorously, in direct relation to urban environments. In order to successfully incorporate conviviality as a new concept for the study of social life in urban space we (1) define it within the body of urban studies knowledge, (2) describe it conceptually, through three main indicators that we refer to as dimensions (flexibility, equity and adaptability), and (3) inform about how it can be studied and therefore "grown", through the design of a list of attributes to look for. This paper focuses on step number 2: the conceptualization process.

As mentioned in the introduction, we carefully chose the term conviviality to avoid the social "baggage" of the widely used term community. If we look at the French cognate ${ }^{13}$, convivialite, we find a definition for conviviality that can be used to describe the social life of places characterized by tolerance and mutual exchange of ideas. Conviviality derives from the Latin convīviālis (festal), equivalent to the Latin convivi (um) or feast and convīv (ere), to live together and/or dine together. Another interesting finding that adds richness to the use of this term is that the equivalent cognate in Spanish, convivencia or coexistence, when used as a name: La Convivencia, describes the period of Spanish history before 1492, when the Muslims, Christians and Jews lived in relative peace. For all of these reasons we decided to expand the meaning of the term conviviality, from the English ones "relating to social events ... eat,

\footnotetext{
${ }^{7}$ Ivan Illich, Tools for conviviality. (New York: Harper \& Row, 1973);

A. Bonnett, "Radicalism, antiracism, and nostalgia: The burden of loss in the search for convivial culture." Environment and Planning A 42,10 (2010): 2351-2369.

8 Jan Gehl, Public spaces \& public life study: City of Adelaide 2011 (Copenhagen, Denmark: Gehl Architects ApS., 2011)

9 Franco La Cecla, and Mairin O'Mahony, Against architecture (San Francisco, Oakland: Green Arcade/PM Press, 2012); Vincent Scully and Neil Levine, Modern architecture and other essays (Princeton, NJ : Princeton University Press, 2003)

${ }^{10}$ Robert D. Putnam, Bowling alone: The collapse and revival of american community (New York: Simon \& Schuster, 2000);

Ray Oldenburg, The great good place : Cafés, coffee shops, community centers, beauty parlors, general stores, bars, hangouts, and how they get you through the day (New York: Paragon House, 1989)

${ }^{11}$ Sharon Zukin, Naked city: The death and life of authentic urban places (Oxford; New York: Oxford University Press, 2010); David Harvey, Social justice and the city. (University of Georgia Press [database online], 2009).

12 Beltran and Simon, "Towards a Definition of Convivial Urban Spaces"

13 "Capacité d'une société à favoriser la tolérance et les échanges réciproques des personnes et des groupes qui la composent" (Larousse 2015), or "ability of a society to promote tolerance and mutual exchange of ideas among the people and groups that compose it." (translated by the authors)
} 
drink, and talk in a friendly way with others" and "friendliness,", to describe social interactions among diverse users of public spaces.

Few studies in the urban field have used the term convivial. Shaftoe ${ }^{15}$ has looked at the characteristics of convivial places and uses the term to refer to places, rather than people. Even though he is using it to describe places, he explains conviviality less like referring to the physical reality of a place and more as a subjective feeling evoked by the place. Shaftoe backs up his definition of conviviality with previous arguments and studies from several scholars: "convivial urban spaces are more than just arenas in which people can have a jolly good time; they are at the heart of democratic living [...] and are one of the few remaining loci where we can encounter difference and learn to understand and tolerate other people." ${ }^{16}$ He claims to have coined the term "convivial spaces" to describe "open, public locations (usually squares and plazas) where citizens can gather, linger or wander through." Even though he is indeed describing convivial places and tries to expand the meaning of conviviality, his understanding of the term derives basically from the English meaning, "being friendly and lively," which we consider valid but not sufficient to study the problem at hand.

In our research, the term conviviality has the potential to describe social interactions in environments characterized by population diversity. As rapid urbanization takes place around the world and urban places in the United States and Europe in particular become increasingly diverse, it is important for urban designers to understand how to design for and measure positive human interaction among diverse groups in public spaces. All of these findings led us to the following definition: Conviviality describes a type of social life in urban places. Convivial places are characterized by being friendly and lively. Convivial places promote tolerance and mutual exchange of ideas among the people and groups that inhabit them.

\footnotetext{
${ }^{14}$ Webster's Dictionary 2015

${ }^{15}$ Henry Shaftoe, Convivial urban spaces: Creating effective public places (London; Sterling, VA: Earthscan in association with the International Institute for Environment and Development, 2008)

${ }^{16}$ Shaftoe, Convivial urban spaces, 12
} 


\section{Conceptualize Conviviality}

The Process

Figure 1. Idea-set that Collects the Dimensions for Conviviality, Extracted from the Study of the Concepts of 'Sociability' and 'Liveliness.' And their Translation into the Three Design Attributes to Look for

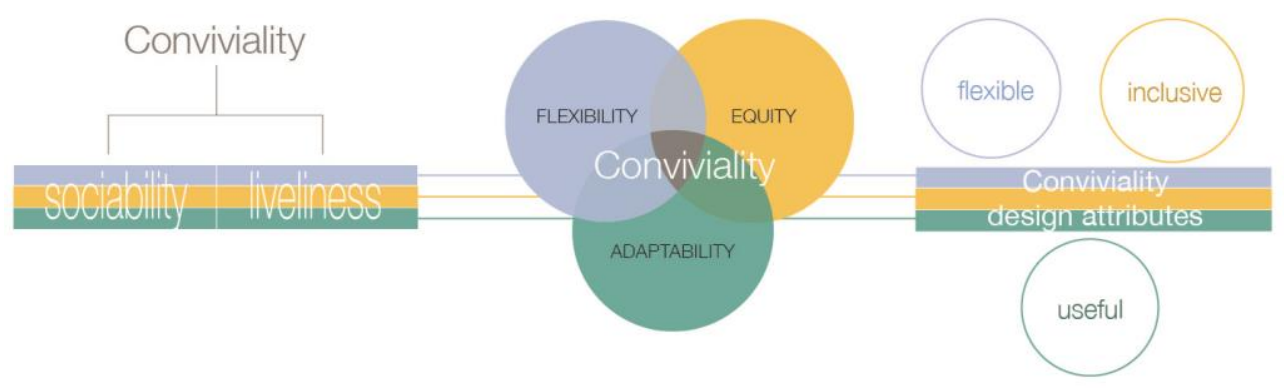

Source: Done by the Authors of this Paper

Through a literature review, we refined and defined in-depth what the concept of conviviality is when applied to the urban design field. The method we used to polish a conviviality concept was combining two of its synonyms: 'sociability' and 'liveliness,' which are used often in urban studies and research of the public realm to describe public places that enjoy quality social interaction (Figure 1). Three areas leap out as most relevant. We have termed these 'dimensions', in order to consolidate the terminology. These three dimensions are identified as necessary conditions for conviviality to 'flourish' in the built environment: equity, flexibility, and adaptability. These three conditions have been translated into three equivalent design attributes of urban landscapes that can be objectively observed: flexible, inclusive and useful. (Figure 1).

In the table below (Figure 2) we have summarized the main authors examined, with their key terms. We have highlighted with different codes those that can be identified with the concept of 'sociability' and those more associated with studies on 'liveliness.' Shaftoe's study stands out as the only one to use the term conviviality. 
Figure 2. Timeline of Authors and Concepts Associated with Liveliness and Sociability

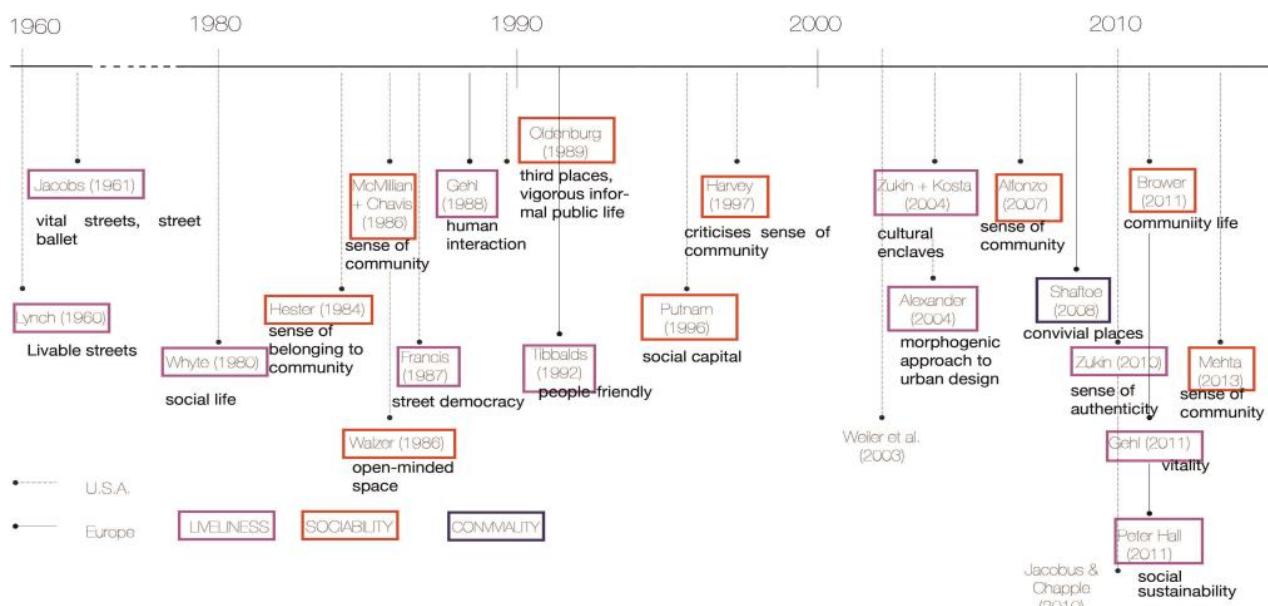

Source: Done by the Authors of this Paper

Under the umbrella of sociability, we identified terms and concepts linked to their main proponents, such as 'sense of belonging', 'sense of community', 'social capital' or 'open-minded space' (Figure 2). Under the umbrella of liveliness, we identified the terms 'vitality', 'street democracy', 'morphogenic', and 'social sustainability.' We found out many of these terms were only partial synonyms of conviviality, but we also discovered three main recurring themes in which all of them intersect: our three dimensions of conviviality (Figure 3).

Figure 3. Timeline of Authors and Concepts and the Three Dimensions of Conviviality

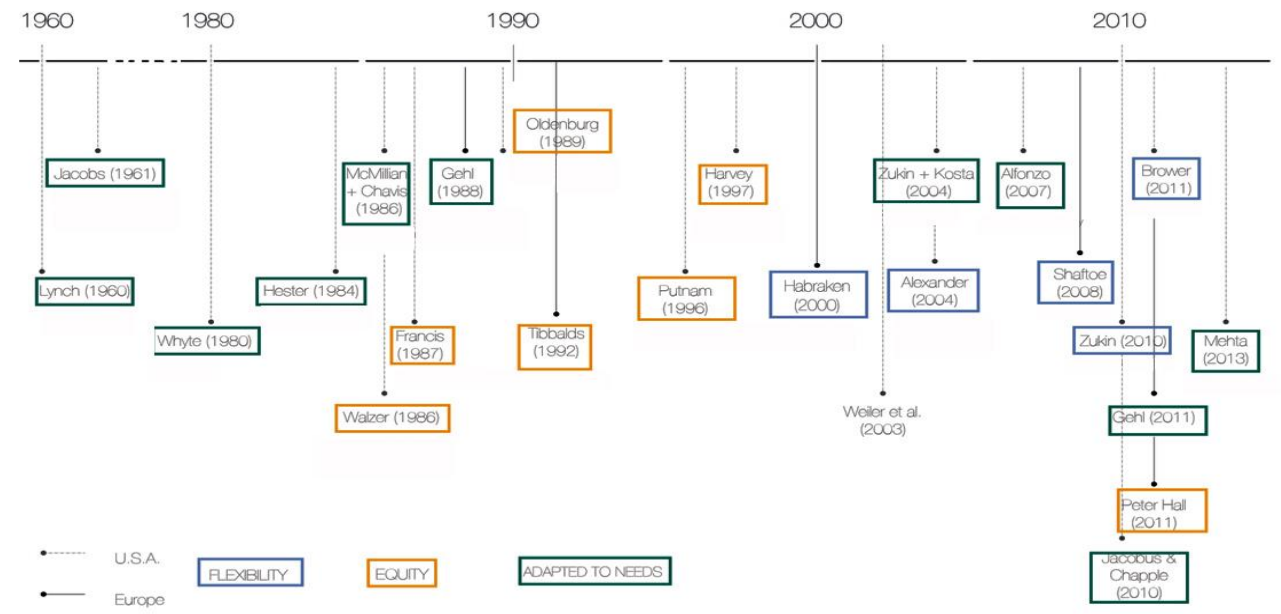

Source: Done by the Authors of this Paper

Findings: The Three Dimensions of Conviviality

Flexibility

'Flexible' is defined as "capable of bending or being bent; easily changed; able to change or to do different things; characterized by a ready capability to 
adapt to new, different, or changing requirements." ${ }^{, 17}$ When applied directly to public spaces in general and urban landscapes in particular, 'flexible' means to be able to adapt in time to changing requirements. From the three dimensions described here, 'flexibility' is the one most associated with design and with the physical realm (architecture, landscape architecture, urban design.) It might refer to how 'flexible' or subject to change are the elements of a landscape, such as its border or perimeter, the objects within it, the paths, materials, etc.

A socially successful place cannot be designed from scratch, it is an 'evolved place, ${ }^{18}$. Authors like Rudofsky ${ }^{19}$ and Alexander ${ }^{20}$ suggest that we are better off 'growing' good places and spaces, rather than trying to build them from plans. Similarly, Habraken ${ }^{21}$ makes a biological analogy, "...the very durability and transcendence of built environment is possible only because there is continuous change. In this respect, built environment is indeed organic: continuous renewal and replacement of individual cells preserves it, giving it the ability to persist."

Historically, most towns and cities grew organically. In the early $20^{\text {th }}$ Century however, modernists proclaimed the city as a machine for living. ${ }^{22}$ A century later some theorists are reclaiming the organic view of the city. Landry $^{23}$ asserts that city making is not a science; it is an art. A city is preferably created by 'the people' who mold the physical as well as its use and how it feels. Shaftoe ${ }^{24}$ cites Alexander ${ }^{25}$, and what he calls the morphogenic approach to urban design as the only true form of built-environment sustainability, because it produces wholeness for the future that is the physical manifestation of our social and cultural aspirations. Shaftoe wonders why we do not really implement an organic, incremental approach to urban design, since it appears to lead to so much more 'people-friendly' environments. $\mathrm{He}$ cites, as one of the main reasons for this lack, suffocating legislation - from planning to building-codes and regulations - that creates a rigid system of predetermined strategies and designs. He also points out that few architects and planners revisit the developments they helped form to see how they have served people over the years.

\footnotetext{
${ }^{17}$ Merriam-Webster's Dictionary, 2015

${ }^{18}$ Shaftoe, Convivial urban spaces

19 Bernard Rudofsky, Architecture without architects, an introduction to nonpedigreed architecture (New York,: Museum of Modern Art; distributed by Doubleday, Garden City, N.Y., 1964)

${ }^{20}$ Christopher Alexander, Sara Ishikawa, Murray Silverstein, A pattern language: Towns, buildings, construction (New York: Oxford University Press, 1977) Christopher Alexander, The timeless way of building (Center for environmental structure series; V. 1; center for environmental structure series ; V. 1. New York : Oxford University Press, 1979)

${ }^{21}$ N. J. Habraken, and Jonathan Teicher, The structure of the ordinary : Form and control in the built environment (Cambridge, Mass.: MIT Press, 1998), 6-7

${ }^{22}$ Le Corbusier, The athens charter [by] le Corbusier (New York,: Grossman, 1973)

${ }^{23}$ Charles Landry, The art of city-making (Sterling, VA: Earthscan, 2006)

${ }^{24}$ Shaftoe, Convivial urban spaces

${ }^{25}$ Alexander, The timeless way of building
} 


\section{Equity}

The definition of 'equity' applied to this research is "fairness or justice in the way people are treated. Something that is 'equitable' deals fairly and equally with all concerned." ${ }^{26}$ When applied to urban landscapes, we use equity as a characteristic, whether everybody is welcome -directly and indirectly- in that space, if they are part of the process, etc. Unlike the previous dimension of flexibility, which was linked directly with the built environment, 'equity' is more directly related to people, and their rights and perceptions in relation to public spaces in the city. This dimension is therefore more closely related to the spheres of social justice and community planning. Convivial urban places are spaces that are sociable and livable, where people enjoy spending time. But they must also be places where difference can exist, where we tolerate those that are different from us, and we all share a common space. ${ }^{27}$

Mark Francis ${ }^{28}$ uses the term 'street democracy' to describe those streets that have meaning for people that invite access for all, and encourage use and participation. Already in the $1980 \mathrm{~s}$, he pointed out that these basic qualities might be vanishing from our towns, cities, and neighborhoods. Jan Gehl ${ }^{29}$ unites the terms social sustainability and democracy in his studies and discourse. After observing public life in the squares of Italian cities, Gehl developed his methods for interpreting human behavior in relation to spatial configuration. "Cities must urge urban planners and architects to reinforce pedestrianism as an integrated city policy to develop lively, safe, sustainable and healthy cities. It is equally urgent to strengthen the social function of city space as a meeting place that contributes toward the aims of social sustainability and an open and democratic society." ${ }^{30}$

\section{Adaptability}

'Adaptable' means, among other things, "able to change or be changed in order to fit or work better in some situation or for some purpose: able to adapt or be adapted." ${ }_{31}$ This definition might lead us to consider the term adaptable as a synonym of 'flexible', but we want to draw a distinction, since in our research the two terms refer to different aspects of an urban landscape. 'Flexible' is a physical quality, an intrinsic characteristic of something that enables it to change, but does not imply the motivation for change. The key point about 'adaptable' is that it refers directly to a purpose. Something might be 'flexible' but still not adaptable or suited to a certain situation or purpose. In particular, the purpose we connect directly to 'adaptability' is people's needs. So when talking about urban landscapes, we use adaptability to refer to how well suited that space is to the needs and characteristics of users and neighbors. Adaptability involves not only the physical (like 'flexibility') or the people

\footnotetext{
${ }^{26}$ Merriam-Webster's Dictionary, 2015

${ }^{27}$ Shaftoe, Convivial urban spaces

${ }^{28}$ C.C. Marcus, and C. Francis, People places: Design guidelines for urban open space (New York : Van Nostrand Reinhold, 1990)

${ }^{29} \mathrm{Gehl}$, Public spaces \& public life study

${ }^{30} \mathrm{Gehl}$, Public spaces \& public life study, 6

${ }^{31}$ Merriam-Webster's Dictionary, 2015
} 
(like 'equity'), but reflects to a direct combination or overlap of both: people's actions in the built environment (urban planning and policy making).

All people share common needs with one other, but each person also has unique needs and ways of expressing and satisfying those needs. The process of neighborhood design involves balancing common needs with individual ones. Knowing what shared needs to expect is important, but discovering the unique needs of a neighborhood is key to socially suitable design because it is the "idiosyncratic needs that generate idiosyncratic values, which in turn generate idiosyncratic but appropriate neighborhood spaces." ${ }^{32}$ An interesting debate is the relationship between the designer or planner and the potential user of a space. Designers and planners with a sustainability ethic take into account the needs of the future users of the spaces they design. Shaftoe ${ }^{33}$ explains that the only difference between a master-planned, fixed urban design approach and a more incremental organic one is the fact that one is a top-down, controlling system of dealing with the built environment and the other is a bottom-up, democratic one. Furthermore, the first describes a situation where people have to adapt to a predetermined environment, and the second one promotes the creation of environments that can be adapted to best meet people's needs.

\section{Pilot Study: Testing the Concept in Superkilen}

Moving forward, in order to fully incorporate the term conviviality into the pool of knowledge of urban design studies, we need to provide information about how the concept can be found and therefore "grown". For practicality matters, the three conditions for conviviality from the literature described previously (flexibility, equity and adaptability) have been translated into three equivalent design qualities of urban landscapes that can be objectively observed: flexible, inclusive and useful. By flexible we understand a design that can be changed by people and can be used in different ways for different activities; by inclusive, we understand a design that can be accessible to everyone and by useful a design that has a purpose other than the merely aesthetic one.

In contrasting the literature findings, as a first step we have conducted a pilot study in a 'people's park', Superkilen (Copenhagen, Denmark). This urban landscape was selected as a case study, among many other parks designed recently, for a number of reasons. It is a newly built contemporary urban park (opened in June 2012) that falls into the category of what has been described as 'people's park ${ }^{\text {, }}$. It is not strictly 'green' in the traditional sense of a park, and has a heavy dose of design and program components. It was built as a result of public initiatives, with an emphasis on participatory practices and social integration goals, since it is located in a multi-cultural and multi-ethnic

\footnotetext{
${ }^{32}$ Randolph T., Hester, Planning neighborhood space with people (New York: Van Nostrand Reinhold Co., 1984), 57

${ }^{33}$ Shaftoe, Convivial urban spaces

${ }^{34}$ Steenbergen, "The Formal Strategy and Grammar of Landscape Architecture"
} 
neighborhood of Copenhagen, Nørrebro. It was designed through a collaboration of well-known architects (BIG), landscape architects (TOPOTEK 1), and artists (SUPERFLEX) that worked together with neighbors and users to select certain design elements for the park. It has won prestigious national and international awards. All of these characteristics make it very relevant in trying to answer the questions this research frames.

Figure 4. Map of Superkilen with a Selection of Objects

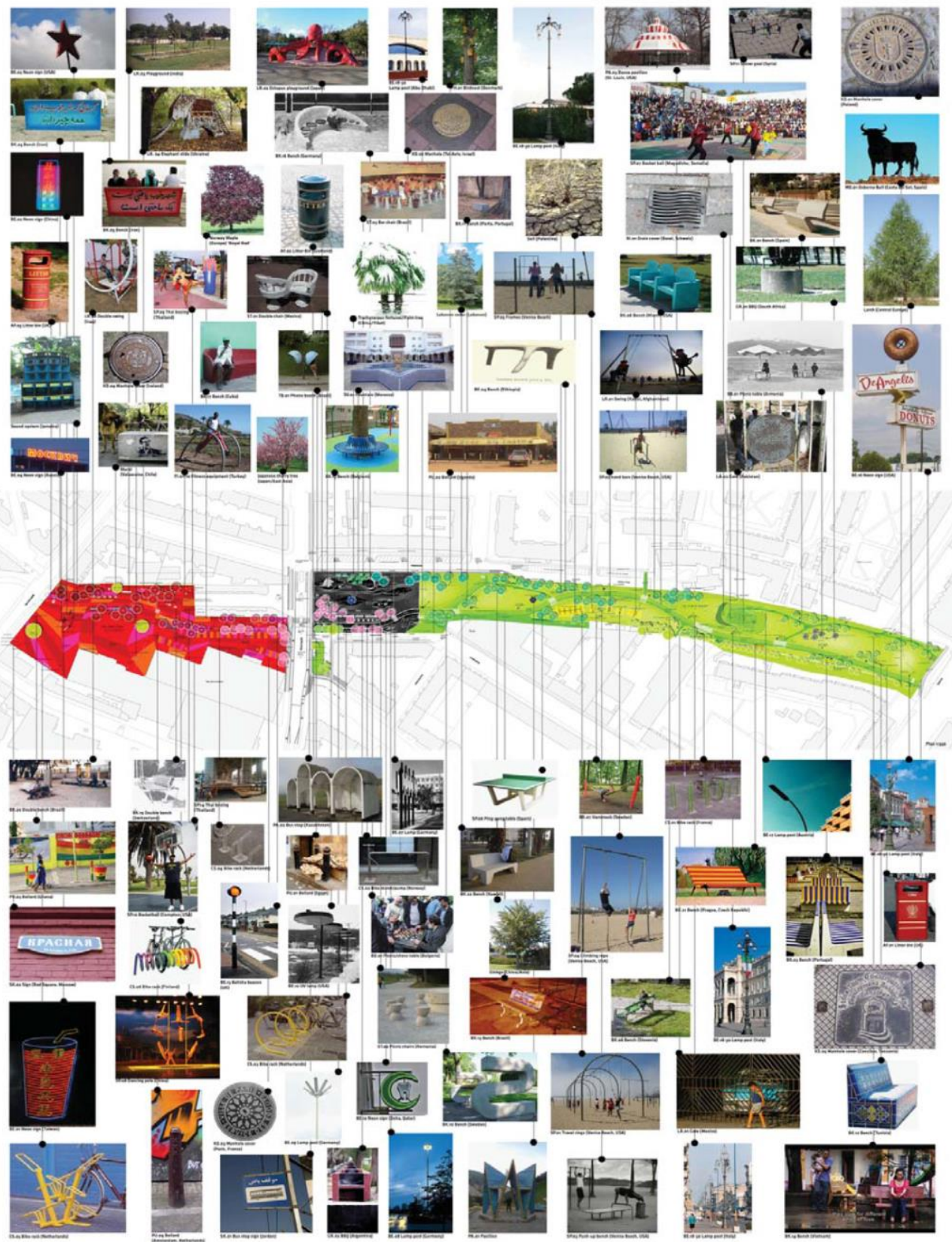

Source: Superkilen: A Project by BIG, TOPOTEK 1, SUPERFLEX ${ }^{35}$

${ }^{35}$ Barbara Steiner, BIG Bjarke Ingels Group, Topotek 1, and Superflex, Superkilen: A Project by BIG, TOPOTEK 1, SUPERFLEX (Stockholm: Arvinius + Orfeus, 2013) 
Figure 4 shows a map of Superkilen and the objects in it that the designers chose as representative of neighbors and potential users of the park. The first thing we did when arriving to the site, was making an inventory of the objects that were being treated as only symbols or art -something to look at- (i.e. the bull, the doughnut), the objects that had one specific function but did not generate activity around them (i.e. bike racks, manholes, lampposts), and lastly, the objects that created what we have described as convivial activity around them (i.e. some benches, playgrounds). This last category of objects is the one we are more interested in, to answer the questions in our research. We noticed that those objects that were flexible, inclusive and useful were usually frequented by a larger variety of people, so they had the potential of being more convivial. Furthermore, we saw these were usually part of a group of objects that together made up an area, an area that at least from the outside and in appearance seemed very convivial.

Figure 5 shows three examples we have picked of spaces that share the attributes of being flexible, inclusive and useful and that in appearance were all very convivial, at different times of the day and different days of the week. We selected one from each color or thematic zone in the park. In the red area, the swing bench from Baghdad, concentrated generally a wide array of people from different ages, ethnicities, etc. Even though it is an object usually meant for children, in this park it is dimensioned also to be used by adults, therefore it is inclusive. Furthermore, there are 6 swings, each for at least 4 people, which makes it even more inclusive. In terms of its flexible attribute, not only it is a design that can be manipulated and moved by people, but it can also be used for different purposes and in different ways, so it is fairly flexible. The swings can be used individually or in groups, while moving or while being fixed. Lastly, it is a design that is inevitably useful in many ways: it can be used to play, eat, chat, wait, etc., all of these activities fairly common in a people's park.

Figure 5. Diagram Showing Three Examples of Flexible, Inclusive and Useful Design in Superkilen Park

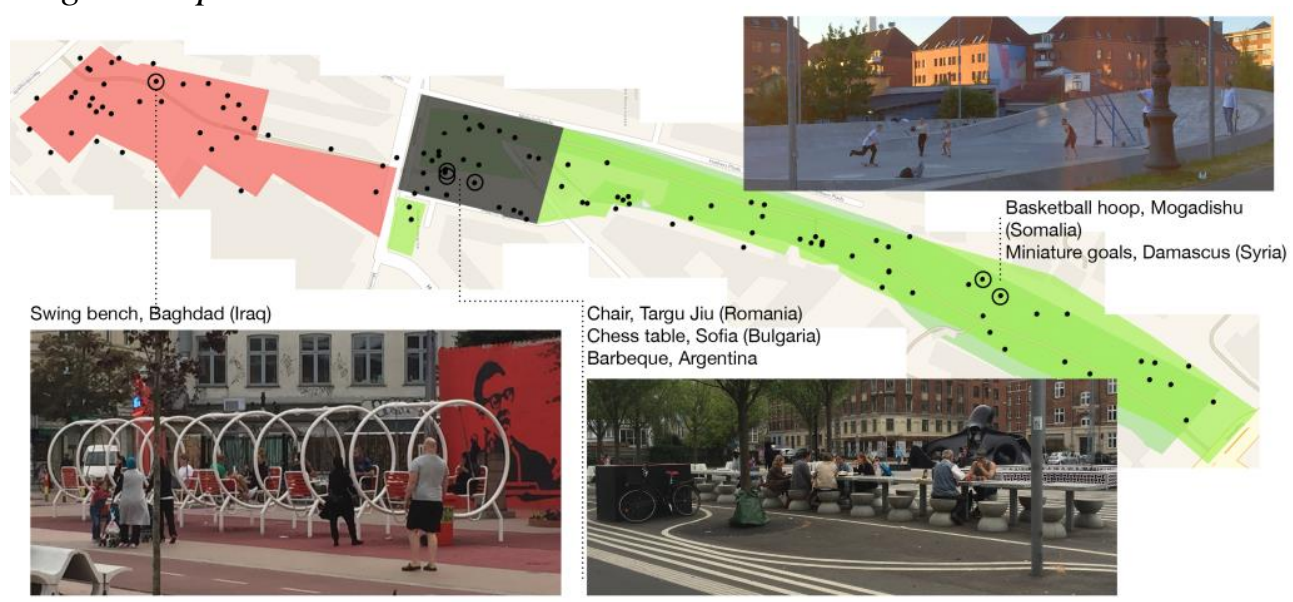

Source: Photographs from the Authors. Map Modified from the One in the Phone Application 'Superkilen' 
The other two examples shown in Figure 5 share many of the characteristics of the swing, in addition to being composed of a group of different objects (instead of only a repetition of the same one). In the example in the center, we see chairs from Romania, Chess tables from Bulgaria, and barbecues from Argentina. All of which create a very convivial setting, especially around lunchtime and dinnertime. Even though the chairs are made of concrete and fixed to the ground, they are flexible in the sense that one can sit facing any side (they don't have a back). The chairs can be used to look into the park -more like an individual bench- or to face towards the table, either on your own or with a group of people. The chess tables serve for many purposes, playing chess (different tables have different game patterns drawn on them), but also eating, reading, working. These make them very useful and flexible. We also determined the area is highly inclusive, for various reasons. People can grill their own food there or bring it cooked from home, or even buy it in a place nearby and sit there to eat it. It is accessible from any of its sides and there are even sides where there are no chairs and a wheelchair or a stroller can be allocated.

The third example shown in Figure 5, on the left, is a space that is used simultaneously as a soccer field, a basketball court, a piazza and a skating park. This space was found to be very convivial, especially in the afternoons and evenings. It is extremely flexible, since the design itself allows for people to do different activities simultaneously or at different times of the day, such as chatting and skating, and with the inclusion of very few objects (basketball hoops from Somalia and miniature goals from Syria), accommodates for more specific activities, such as football and basketball. It is also very inclusive, since it is visible from the main paths as well as directly accessible by wheels through paths and ramps and it doesn't have a gate like many courts of this type usually have. Obviously, on top of being flexible and inclusive, it is extremely useful. Its perimeter can be used as a bench; either facing the courts (to watch others play) or facing the paths and surroundings, but it can also be used for skating. The topography of the court allows people to play different games, on top of being able to skate, or it can simply be used to pass through when using a bicycle, since it is directly connected to the main paths. All of the attributes in these examples (among others in Superkilen), make it a very convivial place, where people from different ages, tastes, styles, ethnicities, etc., seem to coexist in a friendly way, exactly in the manner we have defined as 'convivial' in this research.

\section{Conclusions}

What we conclude from this first study is that there seems to be evidence that the design attributes that were found to be important for conviviality in the literature, do promote convivial attitudes in real settings. The next step in this research is to support this evidence gathered from direct observation onsite, with more data gathered from users. A survey will be conducted in Superkilen, 
in order to find out more about why people act in a convivial way around these spaces that are flexible, inclusive and useful and see any correlations with the observations. We also want to find out whether the symbols or art objects in Superkilen were partly responsible for its high conviviality performance. Answering these questions can help us guide the type of design a people's park could include and how it can be maintained socially -not only physically-, in order to enhance conviviality among its users. The findings can also be extended to other contexts. A better understanding of the relationship between design and user's conviviality can inform architects, landscape architects, urban designers and planners on how to improve the public realm at the scale of the street, the neighborhood and even the city.

\section{Bibliography}

Alexander, C., S. Ishikawa and M. Silverstein. A pattern language: towns, buildings, construction. New York: Oxford University Press, 1977.

Alexander C. The timeless way of building. New York: Oxford University Press, 1979.

Beltran, Maria., and Madlen Simon. "Towards a Definition of Convivial Urban Spaces" (paper presented at the $52^{\text {nd }}$ International Making Cities Livable Conference, Bristol, UK, June 30-July 2, 2015).

Bonnett, A. "Radicalism, antiracism, and nostalgia: The burden of loss in the search for convivial culture." Environment and Planning A 42,10 (2010): 2351-2369.

Czerniak, Julia and George Hargreaves. Large parks. Cambridge, Mass.: Princeton Architectural Press: in association with the Harvard University Graduate School of Design, 2007.

Gehl, Jan. Public spaces \& public life study: City of Adelaide 2011. Copenhagen, Denmark: Gehl Architects ApS., 2011.

Habraken, N.J., and Jonathan Teicher, The structure of the ordinary: Form and control in the built environment. Cambridge, Mass.: MIT Press, 1998.

Hall, Peter (2011). "Social Sustainability, A framework for creating thriving new communities." Design for Social Sustainability by Social Life is licensed under a Creative Commons Attribution-Non- Commercial-NoDerivs 3.0 Unported License. Based on a work at www.social-life.co

Harvey, David. Social justice and the city. University of Georgia Press [database online], 2009.

Illich, Ivan. Tools for conviviality. New York: Harper \& Row, 1973.

Kelly, Social Cities. Australia: Grattan Institute, 2012.

La Cecla, Franco, and Mairin O'Mahony. Against architecture. San Francisco, Oakland: Green Arcade/PM Press, 2012.

Landry, Charles. The art of city-making. Sterling, VA: Earthscan, 2006.

Le Corbusier. The athens charter [by] le Corbusier. New York,: Grossman, 1973.

Marcus, C.C. and C. Francis. People places: Design guidelines for urban open space. New York : Van Nostrand Reinhold, 1990.

Oldenburg, Ray. The great good place : Cafés, coffee shops, community centers, beauty parlors, general stores, bars, hangouts, and how they get you through the day. New York: Paragon House, 1989.

Putnam, Robert D. Bowling alone: The collapse and revival of american community. New York: Simon \& Schuster, 2000. 
Randolph T., Hester. Planning neighborhood space with people. New York: Van Nostrand Reinhold Co., 1984.

Rudofsky, Bernard. Architecture without architects, an introduction to nonpedigreed architecture. New York,: Museum of Modern Art; distributed by Doubleday, Garden City, N.Y., 1964.

Scully, Vincent and Neil Levine, Modern architecture and other essays (Princeton, NJ: Princeton University Press, 2003)

Shaftoe, Henry. Convivial urban spaces: Creating effective public places. London; Sterling, VA: Earthscan in association with the International Institute for Environment and Development, 2008.

Steenbergen, Clemens "The Formal Strategy and Grammar of Landscape Architecture" in ARRIOLA, A. Modern park design: recent trends, 38 (1993).

Steiner, Barbara, BIG Bjarke Ingels Group, Topotek 1 (Firm), and Superflex (Group of artists). Superkilen: A Project by BIG, TOPOTEK 1, SUPERFLEX. Stockholm: Arvinius + Orfeus, 2013

Zukin, Sharon. Naked city: The death and life of authentic urban places. Oxford; New York: Oxford University Press, 2010. 
